
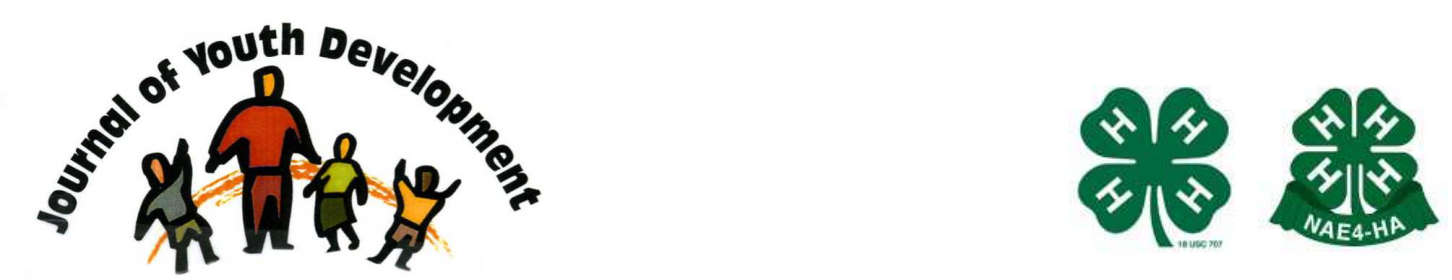

Bridging Research \& Practice

\title{
Building the Capacity of 4-H/Youth Development in Iraq
}

\author{
Patreese D. Ingram \\ The Pennsylvania State University \\ University Park, PA \\ Pdi1@psu.edu \\ Georgene Bender \\ University of Florida \\ Gainesville, FL \\ gmbender@ufl.edu \\ Matt Kreifels \\ University of Nebraska-Lincoln \\ Lincoln, NE \\ mkreifels2@unl.edu \\ Mark Balschweid \\ University of Nebraska-Lincoln \\ Lincoln, NE \\ $\underline{\text { mbalschweid2@unl.edu }}$
}




\title{
JOURNAL OF YOUTH DEVELOPMENT \\ bridging research and practice

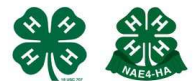

Volume 7, Number 4, Winter 2012

Article 120704FA006

\section{Building the Capacity of 4-H/Youth Development in Iraq}

\author{
Patreese D. Ingram \\ The Pennsylvania State University \\ Georgene Bender \\ University of Florida \\ Matt Kreifels and Mark Balschweid \\ University of Nebraska-Lincoln
}

\begin{abstract}
A team of 4-H/Extension educators were invited to Erbil, Iraq to conduct a week-long intensive training to assist Iraqi youth workers in preparing effective programming as they build their 4-H program. The workshop incorporated the 4-H Essential Elements for Program Success and a Curriculum and Lesson Development Training module. Three-quarters of participants said they were leaving the training with a set of curriculum developed by themselves or others during the workshop. Most (88\%) indicated they had tentative plans for implementing the lessons they developed during the training. This project created a solid foundation upon which Iraqi youth workers can build.
\end{abstract}

\section{Introduction}

The United States Department of Agriculture/Foreign Agricultural Service (USDA/FAS) has been working since 2009 through the use of Provincial Reconstruction Team (PRT) advisors. A relationship with Iraq youth programs began with the efforts of a former U. S. 4-H educator in the Anbar province with the development of the first 4-H youth clubs in 2009 . The first clubs focused on teaching youth to tend sheep. Funding was provided by USDoS (United States Department of State). Over the course of two years the 4-H program grew to include 42 4-H clubs with over 1,100 Iraqi children participating (McPeake, 2011). In 2010, the Iraqi National Center for Youth Clubs was formed. 
Almost half of the Iraqi population is under the age of 18 (Kyriakou, 2005). This population dynamic provides an opportunity to impact the lives and livelihood of future generations of Iraqis in instruction specifically directed at young people. Similar to the approach used in the United States at the turn of the 20th century (History of 4-H, 2011) there exists an opportunity to positively influence the lives of all Iraqi citizens through focused efforts on improved farming techniques and home economics through instruction focused on youth. $4-\mathrm{H}$ is a positive youth development program. The theory of positive youth development:

specifies that if young people have mutually beneficial relationships with the people and institutions of their social world, they will be on the way to a hopeful future marked by positive contributions to self, family, community, and civil society. (Lerner, Almerigi, Theokas, \& Lerner, 2005, p. 12).

According to Karoline Scott, FAS Specialist, " in a country that has been devastated by years of violent conflict, the values and skills Iraqi youth are learning in 4-H clubs are helping achieve a more stable and successful future" (Scott, 2011).

USDA was working in Iraq and through the federal agencies, USDA NIFA's 4-H National Headquarters and FAS (Foreign Ag Service). These federal agencies initiated a collaborative opportunity for land-grant partners who had either experience or involvement with the Iraq 4-H program to participate in developing a weeklong training.

\section{Overall Project Vision and Study Objectives}

\section{Vision}

The overall vision of the Iraqi leadership was to provide sustainable, community-based, positive international youth development programs that

1) Build life skills through agricultural sciences that benefit youth in their careers, improve their economic well-being, and help support their families and communities;

2) Prepare youth for work across the agricultural value chain;

3) Enhance and complement other instruction in language and literacy, computer, math, science, and civic engagement through experiential learning; and,

4) Provide leadership development opportunities that promote interpersonal relations, communication skills, problem solving, teamwork, and character development.

\section{Study Objectives}

In order to positively impact Iraqi youth, training was provided to youth extension agents and youth workers in both government and non-government agencies. Volunteers, who are essential to the success of 4-H youth development programs, need training in effective methodology (Enfield, Schmitt-McQuitty, \& Smith, 2007; VanWinkle, Busler, Bowman, \& Manoogian, 2002). Training in program planning, curriculum development and delivery, and program evaluation are all needed in order to effectively prepare workers for establishing effective youth programs. (Wells, \& Arthur-Banning, 2009).

The objectives for this training project were two-fold:

1. To increase the knowledge and understanding of Iraqi youth workers of the essential elements of 4-H youth development programs, and

2. To strengthen Iraqi youth workers' skills in curriculum development and delivery. 


\section{Methodology}

\section{The Training Process}

The USDA/FAS invited a team of 4-H/Extension experts to conduct a training workshop on program planning and curriculum development and delivery. This activity provided a week-long intensive training workshop to assist Iraqi youth workers in preparing effective programming in working with young people. The training was conducted in Erbil, Iraq. The Iraqi leadership did not wish to simply implement 4-H curriculum that already existed. They wanted the skills to develop curriculum that was relevant and appropriate for Iraqi youth. Seventeen Iraqi youth workers participated in the training.

The team consisted of four agricultural and extension professionals from three land-grant universities including the University of Florida, the University of Nebraska-Lincoln, and the Pennsylvania State University. These professionals brought extensive experiences in rural and urban 4-H programming, agricultural programming in a variety of international settings, training of youth workers and educators, cultural diversity, and program evaluation. Additional trainers from the U.S. consisted of an International Agricultural Development Specialist from the USDA Foreign Agricultural Service and the Director of the National Headquarters for the 4-H Youth Program.

Two in-country college students also assisted the team during the workshop. The purpose of their involvement was to participate in presenting workshop sessions and to further develop the materials presented for future trainings in Iraq. Consultation and materials were also provided by the Penn State 4-H Program Leader. Workshop preparation and planning took place by conference calls, face-to-face meetings, and a conference via Skype with the key Iraqi leader for the project. The groups also met with a local Arabic translator from Iraq who gave the group helpful insight into the culture and assisted with the translation of written material to be used during the in-country workshop and during the web Skype call.

Using the National 4-H Council curriculum entitled Essential Elements of 4-H Youth Development Programs (National 4-H Council, 2009), the facilitation team focused on youth development and program components using an experiential learning model. The curriculum and lesson development training module was based on teaching methods and curriculum planning courses used in agricultural education teacher education programs. The facilitation team provided a basis for curriculum and lesson development. Table 1 presents the schedule that was implemented, incorporating the two components. 
Table 1

Training Implementation Schedule

\begin{tabular}{|c|c|c|}
\hline 5 Days & Essential Elements for Program Success & $\begin{array}{l}\text { Curriculum \& Lesson } \\
\text { Development }\end{array}$ \\
\hline Day 1: & $\begin{array}{l}\text { Session 1: Key Ingredients (Opening Session) } \\
\text { Session 2: A Positive Relationship with a Caring Adult } \\
\text { (Element 1) } \\
\text { Session 3: A Safe Emotional and Physical Environment } \\
\text { (Element 3) }\end{array}$ & $\begin{array}{l}\text { Fundamentals of } \\
\text { Curriculum Development } \\
\text { Units of Study } \\
\text { Lesson Planning } \\
\text { Objectives } \\
\text { Creating Group Lessons }\end{array}$ \\
\hline Day 2: & $\begin{array}{l}\text { Session 4: An Inclusive Environment (Element 2) } \\
\text { Session 5: Engagement in Learning (Element 5) }\end{array}$ & $\begin{array}{l}\text { Modes of Learning } \\
\text { Curriculum Development } \\
\text { Basics } \\
\text { Creating Individual } \\
\text { Lessons }\end{array}$ \\
\hline Day 3: & $\begin{array}{l}\text { Session 6: Opportunity for Mastery (Element 4) } \\
\text { Session 7: Opportunity to See Oneself as an Active } \\
\text { Participant in the Future (Element 6) }\end{array}$ & $\begin{array}{l}\text { Evaluation of Learners } \\
\text { Formatting Lessons into } \\
\text { 4-H Model } \\
\text { Review of Individual } \\
\text { Lessons }\end{array}$ \\
\hline Day 4: & $\begin{array}{l}\text { Session 8: Opportunity for Self-Determination } \\
\text { (Element 7) } \\
\text { Session 9: Opportunity to Value and Practice Service } \\
\text { to Others (Element 8) }\end{array}$ & $\begin{array}{l}\text { Writing Individual Lessons } \\
\text { Lesson Sharing }\end{array}$ \\
\hline Day 5: & $\begin{array}{l}\text { Session 10: Putting it all Together (Concluding } \\
\text { session) }\end{array}$ & $\begin{array}{l}\text { Individual Curriculum } \\
\text { Writing }\end{array}$ \\
\hline
\end{tabular}

To accommodate the language barriers, two translators held a key role in the training program. The translators served as a bridge between the presenters and the participants, writing participant comments in Arabic on flipcharts as the facilitators did the same in English. They also translated the pre and post evaluation forms and facilitated casual comments during break and meal functions as the presenters mingled among the participants. For parts of the workshop presentations a simultaneous translation system was used.

\section{Data Analysis}

A pre-post-evaluation was used to assess the objectives of the training. The evaluation was designed to measure the knowledge, attitudes, and intentions of Iraqi participants related to youth development programming. Session 1 of the training provided awareness of the eight essential elements of positive youth development, as well as participants' role in intentionally planning, implementing and achieving a balanced youth development program. A portion of each day also focused on concepts related to curriculum development. Each item was rated on the extent to which participants agreed with the statement using the following five point Likerttype scale: Strongly Disagree $=1$, Disagree $=2$, Neutral $=3$, Agree $=4$, and Strongly Agree $=5$. Participants were asked to rate between five and eight statements related to each of the eight essential elements that were the focus of the training program in Sessions 2 through 9.

Data were analyzed using SPSS version 19. Descriptive statistics included frequencies, means, and standard deviations. Inferential statistics including paired t-tests were used to compare mean scores before and after the training. The level of significance was set a priori at $p<.05$. 


\section{Findings}

\section{Objective 1}

The tables below report percentages of respondents who "agreed" or "strongly agreed" with each statement. A comparison of means and percentages to responses Before the Training with responses After the Training indicate that the training program had a measureable impact on the degree to which the participants' knowledge, attitudes, and intentions changed related to youth development programming.

Competencies related to the essential elements for program success were represented by 60 competency statements. The percentage of participants who "agreed" or "strongly agreed" with the competency statements After the Training ranged from $76.4 \%-100 \%$, with 30 of the 60 competency statements rated as $100 \%$. The mean scores for 58 of the 60 competency statements increased after the training when compared to the scores before the training. The increase in mean scores was statistically significant for 36 of the 60 statements.

Table 2 presents the percentage of agreement with each competency statement related to understanding the essential elements of positive youth development (Session 1) before and after the training. For each competency statement, the increase in mean scores after the training was statistically significant.

Table 2

Percentage of Agreement, Mean Scores, and t-test Results for Competency Statements Before and After the Training: Session 1 Essential Elements

\begin{tabular}{|l|c|c|c|c|c|c|c|c|c|c|}
\hline & \multicolumn{3}{|c|}{ Before } & \multicolumn{5}{c|}{ After } \\
\hline $\begin{array}{l}\text { I can identify the key } \\
\text { ingredients (Essential } \\
\text { Elements) of Positive Youth } \\
\text { Development. }\end{array}$ & 17 & 70.6 & 3.5 & 1.12 & 17 & 100.0 & 4.4 & .514 & $.011^{*}$ \\
\hline $\begin{array}{l}\text { I understand and can explain } \\
\text { the essential elements to } \\
\text { others. }\end{array}$ & 16 & 62.6 & 3.3 & 1.13 & 17 & 100.0 & 4.4 & .514 & $.008^{*}$ \\
\hline $\begin{array}{l}\text { I can discuss the essential } \\
\text { elements with ease with other } \\
\text { volunteers/staff. }\end{array}$ & 17 & 70.5 & 3.5 & 1.09 & 16 & 93.8 & 4.5 & .624 & $.016^{*}$ \\
\hline $\begin{array}{l}\text { I can lead discussions related } \\
\text { to the activities used to teach } \\
\text { an overview of the essential } \\
\text { elements. }\end{array}$ & 17 & 70.6 & 3.5 & 1.12 & 17 & 100.0 & 4.4 & .514 & $.011^{*}$ \\
\hline $\begin{array}{l}\text { I can compare the different } \\
\text { ingredients that make a youth } \\
\text { program work. }\end{array}$ & 17 & 70.5 & 3.6 & 1.11 & 17 & 100.0 & 4.3 & .492 & $.041^{*}$ \\
\hline $\begin{array}{l}\text { I can distinguish each } \\
\text { essential element from the } \\
\text { others. }\end{array}$ & 17 & 58.8 & 3.2 & 1.13 & 17 & 76.4 & 3.9 & .658 & $.038^{*}$ \\
\hline
\end{tabular}

Note. $\mathrm{A} / \mathrm{SA}=$ agree or strongly agree; ${ }^{*} p<.05$ 
Table 3 presents the percentage of agreement with each competency statement related to developing positive relationships with a caring adult (Session 2) before and after the training. There was a statistically significant difference in scores for four of the eight statements before and after the training.

Table 3

Percentage of Agreement, Mean Scores, and t-test Results for Competency Statements Before and After the Training: Session 2 - A Positive Relationship w/ Caring Adult

\begin{tabular}{|l|c|c|c|c|c|c|c|c|c|}
\hline & \multicolumn{3}{|c|}{ Before } & \multicolumn{3}{c|}{ After } \\
\hline $\begin{array}{l}\text { I recall the key points in a } \\
\text { caring relationship between a } \\
\text { youth and an adult volunteer. }\end{array}$ & 17 & 70.6 & 3.5 & 1.12 & 17 & 94.1 & 4.2 & .562 & $.041^{*}$ \\
\hline $\begin{array}{l}\text { I can repeat the important } \\
\text { concepts of a positive } \\
\text { relationship with a caring } \\
\text { adult to other } \\
\text { volunteers/staff. }\end{array}$ & 16 & 68.8 & 3.5 & 1.03 & 16 & 94.1 & 4.2 & .447 & $.009 *$ \\
\hline $\begin{array}{l}\text { I can discuss the essential } \\
\text { elements with ease with other } \\
\text { volunteers/staff. }\end{array}$ & 17 & 82.4 & 4.0 & .966 & 17 & 94.1 & 4.3 & .606 & .289 \\
\hline $\begin{array}{l}\text { I understand the importance } \\
\text { of a positive relationship with } \\
\text { a caring adult. }\end{array}$ & 16 & 58.8 & 3.6 & 1.13 & 16 & 81.3 & 4.1 & .718 & .234 \\
\hline $\begin{array}{l}\text { I am able to explain to others } \\
\text { new concepts relating to } \\
\text { positive relationships. }\end{array}$ & 16 & 64.7 & 3.3 & 1.36 & 17 & 82.3 & 4.1 & .696 & .061 \\
\hline $\begin{array}{l}\text { I can choose activities to } \\
\text { teach the key concepts of } \\
\text { positive relationships between } \\
\text { youth and adults. }\end{array}$ & 16 & 68.8 & 3.5 & 1.31 & 17 & 94.2 & 4.4 & .619 & $.011^{*}$ \\
\hline $\begin{array}{l}\text { I know the difference } \\
\text { between a positive and a } \\
\text { negative relationship. }\end{array}$ & 16 & 75.1 & 3.8 & .910 & 17 & 94.2 & 4.4 & .629 \\
\hline $\begin{array}{l}\text { I can appraise youth } \\
\text { development environments to } \\
\text { determine if they support } \\
\text { positive relationships. }\end{array}$ & 16 & 68.8 & 3.4 & 1.15 & 17 & 81.3 & 4.0 & .680 & $.020^{*}$ \\
\hline
\end{tabular}

Note. $\mathrm{A} / \mathrm{SA}=$ agree or strongly agree; ${ }^{*} p<.05$ 
Table 4 presents the percentage of agreement with each competency statement related to creating a safe emotional and physical environment (Session 3) before and after the training. For each of the six statements, there was a statistically significant increase in scores before and after the training.

Table 4

Percentage of Agreement, Mean Scores, and t-test Results for Competency Statements Before and After the Training: Session 3 - A Safe Emotional and Physical Environment

\begin{tabular}{|l|c|c|c|c|c|c|c|c|c|c|}
\hline & \multicolumn{3}{|c|}{ Before } & \multicolumn{3}{c|}{ After } \\
\hline $\begin{array}{l}\text { I can define what safe } \\
\text { emotional and physical } \\
\text { environments look like. }\end{array}$ & 17 & 58.5 & 3.3 & 1.21 & 17 & 88.2 & 4.1 & .635 & $.009 *$ \\
\hline $\begin{array}{l}\text { I can list various elements that } \\
\text { create a safe emotional or } \\
\text { physical environment. }\end{array}$ & 16 & 56.3 & 3.2 & 1.04 & 17 & 94.1 & 4.2 & .528 & $.003 *$ \\
\hline $\begin{array}{l}\text { I can explain to other } \\
\text { volunteers/staff the } \\
\text { importance of understanding } \\
\text { safe emotional and physical } \\
\text { environments. }\end{array}$ & 16 & 82.4 & 3.7 & .919 & 17 & 100.0 & 4.3 & .492 & $.029 *$ \\
\hline $\begin{array}{l}\text { I can evaluate safe versus } \\
\text { non-safe environments in } \\
\text { youth-adult programs. }\end{array}$ & 17 & 70.6 & 3.5 & 1.12 & 17 & 94.2 & 4.4 & .618 & $.026 *$ \\
\hline $\begin{array}{l}\text { I can implement activities to } \\
\text { further the understanding of } \\
\text { safe emotional and physical } \\
\text { environments. }\end{array}$ & 17 & 64.7 & 3.5 & 1.12 & 17 & 100.0 & 4.2 & .437 & $.029 *$ \\
\hline $\begin{array}{l}\text { I can recognize emotional and } \\
\text { physical safety issues in a } \\
\text { youth development program }\end{array}$ & 16 & 41.2 & 3.0 & 1.11 & 17 & 100.0 & 4.2 & .437 & $.000 *$ \\
\hline
\end{tabular}

Note. $\mathrm{A} / \mathrm{SA}=$ agree or strongly agree; ${ }^{*} p<.05$ 
Table 5 presents the percentage of agreement with each competency statement related to creating an inclusive environment (Session 4) before and after the training. For seven of the eight statements there was a statistically significant difference in scores before and after the training.

Table 5

Percentage of Agreement, Mean Scores, and t-test Results for Competency Statements Before and After the Training: Session 4 - An Inclusive Environment

\begin{tabular}{|c|c|c|c|c|c|c|c|c|c|}
\hline & \multicolumn{4}{|c|}{ Before } & \multicolumn{5}{|c|}{ After } \\
\hline & $\mathbf{N}$ & $\begin{array}{c}\% \\
\text { A/SA }\end{array}$ & $M$ & SD & $\mathbf{N}$ & $\%$ A/SA & $M$ & SD & $\mathbf{p}$ \\
\hline $\begin{array}{l}\text { I can list behaviors or } \\
\text { practices that lead to an } \\
\text { inclusive environment. }\end{array}$ & 17 & 70.6 & 3.5 & .943 & 17 & 100.0 & 4.2 & .437 & $.003 *$ \\
\hline $\begin{array}{l}\text { I can list behaviors or } \\
\text { practices that hinder an } \\
\text { inclusive environment. }\end{array}$ & 17 & 70.6 & 3.3 & 1.05 & 17 & 88.2 & 4.1 & .600 & $.002^{*}$ \\
\hline $\begin{array}{l}\text { I can describe the effects of } \\
\text { power, status, and peer } \\
\text { influence on youth. }\end{array}$ & 16 & 56.3 & 3.3 & 1.01 & 17 & 100.0 & 4.3 & .478 & $.000 *$ \\
\hline $\begin{array}{l}\text { I understand the potential } \\
\text { consequences of acceptance } \\
\text { or rejection. }\end{array}$ & 17 & 47.1 & 3.0 & 1.36 & 17 & 94.1 & 4.2 & .562 & $.001^{*}$ \\
\hline $\begin{array}{l}\text { I can demonstrate program } \\
\text { practices and behaviors that } \\
\text { create an inclusive } \\
\text { environment. }\end{array}$ & 17 & 70.6 & 3.4 & 1.17 & 17 & 94.1 & 4.3 & .587 & $.001^{*}$ \\
\hline $\begin{array}{l}\text { I am likely to use inclusive } \\
\text { practices in my programs. }\end{array}$ & 17 & 70.5 & 3.6 & 1.11 & 17 & 82.3 & 4.0 & .935 & .055 \\
\hline $\begin{array}{l}\text { I can distinguish between an } \\
\text { inclusive and exclusive } \\
\text { environment. }\end{array}$ & 17 & 70.6 & 3.2 & 1.35 & 17 & 88.3 & 4.3 & .701 & $.000 *$ \\
\hline $\begin{array}{l}\text { I can examine my program } \\
\text { and incorporate activities that } \\
\text { create an inclusive } \\
\text { environment. }\end{array}$ & 17 & 58.8 & 3.1 & 1.07 & 17 & 94.1 & 4.1 & .485 & $.002 *$ \\
\hline
\end{tabular}

Note. $\mathrm{A} / \mathrm{SA}=$ agree or strongly agree; $* p<.05$ 
Table 6 presents the percentage of agreement with each competency statement related to engagement in learning (Session 5) before and after the training. For each of the seven statements, there was a statistically significant difference in scores before and after the training.

Table 6

Percentage of Agreement, Mean Scores, and t-test Results for Competency Statements Before and After the Training: Session 5 - Engagement in learning

\begin{tabular}{|l|c|c|c|c|c|c|c|c|c|c|}
\hline & \multicolumn{3}{|c|}{ Before } & \multicolumn{5}{c|}{ After } \\
\hline & $\mathrm{N}$ & $\%$ A/SA & $\mathrm{M}$ & $\mathrm{SD}$ & $\mathrm{N}$ & $\%$ A/SA & $\mathrm{M}$ & SD & $\mathrm{P}$ \\
\hline $\begin{array}{l}\text { I can describe the steps in the } \\
\text { experiential learning cycle. }\end{array}$ & 17 & 57.9 & 3.2 & 1.25 & 17 & 100.0 & 4.1 & .392 & $.004 *$ \\
\hline $\begin{array}{l}\text { I can generate discussion } \\
\text { questions to guide youth } \\
\text { through the experiential } \\
\text { learning process. }\end{array}$ & 17 & 82.3 & 3.7 & 1.25 & 17 & 100.0 & 4.4 & .507 & $.029 *$ \\
\hline $\begin{array}{l}\text { I can explain why experiential } \\
\text { learning is more enjoyable for } \\
\text { youth than lecture style } \\
\text { lessons. }\end{array}$ & 17 & 76.5 & 3.6 & 1.45 & 17 & 100.0 & 4.6 & .492 & $.003 *$ \\
\hline $\begin{array}{l}\text { I can develop an activity using } \\
\text { an active learning strategy. }\end{array}$ & 17 & 58.8 & 3.2 & 1.25 & 17 & 94.1 & 4.1 & .485 & $.003 *$ \\
\hline $\begin{array}{l}\text { I can process an activity using } \\
\text { the experiential learning } \\
\text { process. }\end{array}$ & 17 & 76.4 & 3.7 & 1.26 & 17 & 100.0 & 4.5 & .514 & $.004 *$ \\
\hline $\begin{array}{l}\text { I can modify an activity so } \\
\text { that it uses experiential } \\
\text { learning. }\end{array}$ & 16 & 56.3 & 3.1 & 1.20 & 17 & 100.0 & 4.5 & .512 & $.000 *$ \\
\hline $\begin{array}{l}\text { I can differentiate between } \\
\text { active and passive learning } \\
\text { strategies. }\end{array}$ & 17 & 76.5 & 3.5 & 1.12 & 17 & 100.0 & 4.4 & .507 & $.002 *$ \\
\hline
\end{tabular}

Note. $\mathrm{A} / \mathrm{SA}=$ agree or strongly agree; ${ }^{*} p<.05$ 
Table 7 presents the percentage of agreement with each competency statement related to providing an opportunity for mastery (Session 6) before and after the training. For four of the eight statements, there was a statistically significant increase in scores after the training. The difference in before and after scores was not statistically significant for four competency statements.

Table 7

Percentage of Agreement, Mean Scores, and t-test Results for Competency Statements Before and After the Training: Session 6-Opportunity for Mastery

\begin{tabular}{|c|c|c|c|c|c|c|c|c|c|}
\hline & \multicolumn{4}{|c|}{ Before } & \multicolumn{5}{|c|}{ After } \\
\hline & $\mathbf{N}$ & $\begin{array}{c}\% \\
\text { A/SA }\end{array}$ & $M$ & SD & $\mathbf{N}$ & $\%$ A/SA & $\mathbf{M}$ & SD & $\mathbf{p}$ \\
\hline $\begin{array}{l}\text { I know that opportunity for } \\
\text { mastery is an essential } \\
\text { element of positive youth } \\
\text { development. }\end{array}$ & 16 & 87.6 & 4.1 & 1.14 & 17 & 82.3 & 4.0 & .658 & .580 \\
\hline $\begin{array}{l}\text { I understand and recall the } \\
\text { importance of opportunity for } \\
\text { mastery. }\end{array}$ & 16 & 68.8 & 3.7 & .77 & 17 & 88.3 & 3.9 & .500 & .609 \\
\hline $\begin{array}{l}\text { I can describe the effects of } \\
\text { power, status, and peer } \\
\text { influence on youth. }\end{array}$ & 16 & 75.0 & 3.9 & .95 & 17 & 100.0 & 4.2 & .469 & .164 \\
\hline $\begin{array}{l}\text { I can verbally translate the } \\
\text { importance of mastery to } \\
\text { volunteers/staff. }\end{array}$ & 16 & 75.0 & 3.5 & 1.20 & 16 & 76.5 & 3.8 & .750 & .261 \\
\hline $\begin{array}{l}\text { I can choose appropriate } \\
\text { activities that teach mastery. }\end{array}$ & 16 & 68.8 & 3.5 & 1.12 & 17 & 100.0 & 4.2 & .414 & $.027 *$ \\
\hline $\begin{array}{l}\text { I am likely to use inclusive } \\
\text { practices in my programs. }\end{array}$ & 16 & 50.0 & 3.3 & 1.08 & 17 & 82.3 & 4.0 & .696 & $.000^{*}$ \\
\hline $\begin{array}{l}\text { I can examine and identify } \\
\text { effective hands-on projects in } \\
\text { my youth development work. }\end{array}$ & 16 & 75.0 & 3.6 & 1.08 & 17 & 100.0 & 4.3 & .478 & $.016^{*}$ \\
\hline $\begin{array}{l}\text { I can compare mastery } \\
\text { opportunities and know good } \\
\text { programs from poor ones. }\end{array}$ & 16 & 62.6 & 3.5 & 1.26 & 17 & 100.0 & 4.3 & .478 & $.014^{*}$ \\
\hline
\end{tabular}

Note. $\mathrm{A} / \mathrm{SA}=$ agree or strongly agree; ${ }^{*} p<.05$ 
Table 8 presents the percentage of agreement with each competency statement related to creating an opportunity for youth to see themselves as an active participant in the future (Session 7) before and after the training. The difference between before and after scores was not statistically significant for any of the six competency statements.

Table 8

Percentage of Agreement, Mean Scores, and t-test Results for Competency Statements Before and After The Training: Session 7 - Opportunity to See Oneself as an Active Participant in the Future

\begin{tabular}{|l|c|c|c|c|c|c|c|c|c|}
\hline & \multicolumn{3}{|c|}{ Before } & \multicolumn{3}{c|}{ After } \\
\hline $\begin{array}{l}\text { I know that the opportunity to } \\
\text { see oneself as an active } \\
\text { participant in the future is an } \\
\text { essential element of positive } \\
\text { youth development. }\end{array}$ & 16 & 81.3 & 4.0 & .680 & 17 & 100.0 & 4.2 & .403 & .544 \\
\hline $\begin{array}{l}\text { I know the success in setting } \\
\text { and achieving goals gives } \\
\text { youth the confidence to aspire } \\
\text { to more challenging } \\
\text { accomplishments. }\end{array}$ & 16 & 93.8 & 4.5 & .629 & 17 & 100.0 & 4.4 & .512 & .432 \\
\hline $\begin{array}{l}\text { I can identify valuable } \\
\text { aptitudes, skills and interests } \\
\text { that will help youth be } \\
\text { successful in the future. }\end{array}$ & 16 & 81.3 & 3.9 & .997 & 17 & 100.0 & 4.3 & .478 & .188 \\
\hline $\begin{array}{l}\text { I can demonstrate the SMART } \\
\text { method of goal setting. }\end{array}$ & 16 & 75.1 & 3.9 & .806 & 17 & 88.2 & 4.2 & .655 & .289 \\
\hline $\begin{array}{l}\text { I can help others write goals } \\
\text { and objectives. }\end{array}$ & 16 & 87.6 & 3.9 & .928 & 17 & 100.0 & 4.5 & .516 & .070 \\
\hline $\begin{array}{l}\text { I can identify effective hands- } \\
\text { on projects that promote the } \\
\text { concept of seeing oneself as } \\
\text { an active participant in the } \\
\text { future. }\end{array}$ & 16 & 81.3 & 3.7 & 1.00 & 17 & 100.0 & 4.2 & .447 & .072 \\
\hline
\end{tabular}

Note. $\mathrm{A} / \mathrm{SA}=$ agree or strongly agree; $* p<.05$ 
Table 9 presents the percentage of agreement with each competency statement related to providing youth with an opportunity for self-determination (Session 8) before and after the training. There was a statistically significant difference in scores for one statement before and after the training. The difference in before and after scores was not statistically significant for four competency statements.

\section{Table 9}

Percentage of Agreement, Mean Scores, and t-test Results for Competency Statements Before and After the Training: Session 8 -Opportunity for Self-determination

\begin{tabular}{|c|c|c|c|c|c|c|c|c|c|}
\hline & \multicolumn{4}{|c|}{ Before } & \multicolumn{5}{|c|}{ After } \\
\hline & $\mathrm{N}$ & $\% \mathrm{~A} / \mathrm{SA}$ & $M$ & SD & $\mathrm{N}$ & $\% \mathrm{~A} / \mathrm{SA}$ & $M$ & SD & $p$ \\
\hline $\begin{array}{l}\text { I know the definition of } \\
\text { opportunity for self- } \\
\text { determination. }\end{array}$ & 14 & 78.6 & 3.9 & 615 & 17 & 94.2 & 4.1 & .428 & .500 \\
\hline $\begin{array}{l}\text { I can list examples of self- } \\
\text { determination. }\end{array}$ & 14 & 71.4 & 3.5 & .851 & 17 & 94.2 & 4.1 & .428 & .068 \\
\hline $\begin{array}{l}\text { I can recognize self- } \\
\text { determination in a youth } \\
\text { development program. }\end{array}$ & 14 & 64.2 & 3.5 & .937 & 17 & 94.1 & 4.1 & .485 & .089 \\
\hline $\begin{array}{l}\text { I can explain ideas and } \\
\text { concepts of self-determination } \\
\text { to others. }\end{array}$ & 14 & 71.4 & 3.6 & .928 & 17 & 94.1 & 4.1 & .485 & .089 \\
\hline $\begin{array}{l}\text { I can choose appropriate } \\
\text { activities to promote self- } \\
\text { determination. }\end{array}$ & 14 & 71.4 & 3.7 & .994 & 17 & 100.0 & 4.5 & .514 & $.010^{*}$ \\
\hline
\end{tabular}

Note. $\mathrm{A} / \mathrm{SA}=$ agree or strongly agree; $* p<.05$ 
Table 10 presents the percentage of agreement with each competency statement related to providing an opportunity for youth to value and practice service to others (Session 9) before and after the training. There was a statistically significant difference in scores for one of the six statements before and after the training. The difference in before and after scores was not statistically significant for five competency statements.

Table 10

Percentage of Agreement, Mean Scores, and t-test Results for Competency Statements Before and After the Training: Session 9 - Opportunity to Value and Practice Service to Others

\begin{tabular}{|c|c|c|c|c|c|c|c|c|c|}
\hline & \multicolumn{4}{|c|}{ Before } & \multicolumn{5}{|c|}{ After } \\
\hline & $\mathrm{N}$ & $\% \mathrm{~A} / \mathrm{SA}$ & $M$ & SD & $\mathrm{N}$ & $\% \mathrm{~A} / \mathrm{SA}$ & $M$ & SD & $p$ \\
\hline $\begin{array}{l}\text { I know the opportunity to } \\
\text { value and practice service to } \\
\text { others is one of the essential } \\
\text { elements. }\end{array}$ & 14 & 92.8 & 4.1 & .534 & 17 & 100.0 & 4.5 & .518 & .136 \\
\hline $\begin{array}{l}\text { I can define both community } \\
\text { service and service-learning. }\end{array}$ & 14 & 85.7 & 4.3 & .744 & 17 & 100.0 & 4.4 & .514 & .752 \\
\hline $\begin{array}{l}\text { I can describe the components } \\
\text { necessary for a successful } \\
\text { service-learning activity to } \\
\text { others. }\end{array}$ & 14 & 85.7 & 3.8 & .949 & 17 & 100.0 & 4.0 & .267 & .426 \\
\hline $\begin{array}{l}\text { I can plan a service-learning } \\
\text { project for youth and adults. }\end{array}$ & 14 & 100.0 & 4.3 & .497 & 17 & 100.0 & 4.3 & .469 & .500 \\
\hline $\begin{array}{l}\text { I can examine community } \\
\text { service projects and modify } \\
\text { them into service-learning } \\
\text { projects. }\end{array}$ & 14 & 71.4 & 3.6 & .928 & 17 & 100.0 & 4.2 & .425 & $.040 *$ \\
\hline $\begin{array}{l}\text { I can differentiate between } \\
\text { community service and } \\
\text { service-learning projects. }\end{array}$ & 14 & 85.7 & 4.0 & .554 & 17 & 88.2 & 4.1 & .663 & .547 \\
\hline
\end{tabular}

Note. $\mathrm{A} / \mathrm{SA}=$ agree or strongly agree; $* p<.05$

The competencies in which participants had the greatest gains included:

- Understanding the essential elements of positive youth development

- Creating a safe emotional and physical environment

- Creating an inclusive environment, and

- Engaging youth in experiential learning

The competencies in which participants had the least gains included:

- Providing opportunities for youth to see themselves as an active participant in the future

- Providing opportunities for youth self-determination, and

- Providing opportunities for youth to value and practice service to others 
Table 11 presents the percentage of agreement to each competency statement related to curriculum development concepts. Participants were only asked to rate this competency after the training.

Table 11

Percentage of Agreement and Mean Scores for Competency Statements After the Training: Session 10 - Curriculum Development Concepts

\begin{tabular}{|c|c|c|c|c|}
\hline & $\mathbf{N}$ & $\% A / S A$ & $\mathbf{M}$ & SD \\
\hline $\begin{array}{l}\text { I know the difference between the lecture method } \\
\text { of teaching and the experiential method of } \\
\text { teaching. }\end{array}$ & 17 & 94.1 & 4.5 & .624 \\
\hline $\begin{array}{l}\text { I can identify the requirements for inquiry-based } \\
\text { learning. }\end{array}$ & 17 & 94.1 & 4.1 & .485 \\
\hline $\begin{array}{l}\text { I can explain to others the difference between } \\
\text { open questions and closed questions. }\end{array}$ & 17 & 94.1 & 4.2 & .951 \\
\hline $\begin{array}{l}\text { I can compare the advantages of both open and } \\
\text { closed questions. }\end{array}$ & 17 & 94.1 & 4.0 & .866 \\
\hline $\begin{array}{l}\text { I can explain the advantage of using Wait Time } \\
\text { when questioning youth. }\end{array}$ & 17 & 94.1 & 4.3 & .606 \\
\hline $\begin{array}{l}\text { I can design a lesson using the Backward Design } \\
\text { Method. }\end{array}$ & 17 & 82.4 & 4.2 & .727 \\
\hline $\begin{array}{l}\text { I can name and explain the steps in the 5-Step } \\
\text { Learning Cycle. }\end{array}$ & 17 & 76.5 & 3.9 & 1.02 \\
\hline $\begin{array}{l}\text { I know how to help youth process the learning } \\
\text { experience. }\end{array}$ & 17 & 100.0 & 4.6 & .507 \\
\hline $\begin{array}{l}\text { I can name a variety of ways to determine if the } \\
\text { learner has achieved the desired results of the } \\
\text { lesson. }\end{array}$ & 17 & 100.0 & 4.5 & .514 \\
\hline $\begin{array}{l}\text { I feel confident to create an engaging learning } \\
\text { environment for youth in Iraq. }\end{array}$ & 17 & 94.2 & 4.4 & .618 \\
\hline $\begin{array}{l}\text { I feel prepared to create an engaging learning } \\
\text { environment for youth in Iraq. }\end{array}$ & 17 & 100.0 & 4.6 & .492 \\
\hline
\end{tabular}

Note. $\mathrm{A} / \mathrm{SA}=$ agree or strongly agree

\section{Objective 2}

At the end of the training participants were asked to indicate the degree to which they were ready to apply what they had learned. Three-quarters $(76.4 \%)$ of participants said they were leaving the training with a set of curricula developed by themselves or other participants during the training event. An even greater percentage (88.2\%) indicated they have a tentative plan for implementing the lessons they developed during the training event. Table 12 presents the percentage of agreement to statements related to readiness to apply what had been learned during the training. 
Table 12

Percentage of Participants Who Agree With Being Ready to Apply What They Have Learned After the Training

\begin{tabular}{|l|l|l|l|l|}
\hline & N & \%A/SA & M & SD \\
\hline $\begin{array}{l}\text { I am leaving the training with a set of curriculum } \\
\text { (learning/activity guide templates) developed by myself and/or } \\
\text { other participants during this training event. }\end{array}$ & 17 & $76.4 \%$ & 3.9 & .781 \\
\hline $\begin{array}{l}\text { I have a tentative plan for implementing the lessons that have } \\
\text { been developed during this training event. }\end{array}$ & 16 & 88.2 & 4.2 & .577 \\
\hline
\end{tabular}

Note: $\mathrm{A}=$ Agree, $\mathrm{SA}=$ Strongly Agree

\section{Discussion}

Based upon the results from participants it is clear that the Iraqi workshop participants learned about the elements of experiential learning and methods for incorporating experiential learning methodology into their existing curriculum. Based upon pre- and post-test survey results, they also felt they had learned a significant amount about creating a safe emotional and physical environment for the young people that they work with. And, not only were they able to recognize emotional and physical safety issues for young people in their current development programs, they felt confident that they could share that information to instruct other youth leaders helping them to create similar safe environments.

In two of the major competency areas that resulted in the least gain in means scores (opportunity to see oneself as an active participant in the future, and opportunity to value and practice service to others), the mean scores were rated high before the training and therefore had limited opportunity for growth. The interest in developing self-determination in youth is a new and growing movement in Iraq. An example of this movement is the Third Iraqi Civil Society Solidarity Initiative Conference which was held in Irbil in October of 2011. At that conference, it was declared that, "While youth in Iraq face many challenges, they can be one of the most important forces for change and social progress and the conference supports civil society and government efforts to develop the youth sector" (Iraqi Civil Society, 2011).

\section{Additional Benefits of the Project}

Several additional benefits resulted from this project. Specific benefits include:

- The efforts of the team built upon existing 4-H efforts currently underway in Iraq. Several of the club leaders that came together were able to share ideas across provinces and subject matter. Ideas for recruiting and engaging youth were discussed formally and during breaks and in the evenings and during mealtimes.

- Groups that don't normally interact were able to connect with one another, establish relationships, provide contact information and plan future communications. These groups included government and non-government entities, volunteer organizations, businessmen and women, and those involved in formal education training.

- Youth-based curriculum was developed using curriculum templates that could easily be exchanged across all participants. Although the curriculum developed was in draft form by the end of the workshop, e-mail addresses were collected and efforts were established for the sharing of curricula in final draft form. In addition, the curriculum 
development efforts were targeted to teach the participants the skills necessary to continue developing curriculum long after the workshop was concluded.

- There was $100 \%$ involvement and engagement by all invited youth workers. This was evident in all lesson presentations, curriculum development exercises, and role-play activities. In addition, Iraqi attendees to the workshop were able to practice their English language skills while interacting with the presenters and the language interpreters.

- Iraqi, Kurdish, and U. S. relationships were established and/or strengthened among the participants. Several instances throughout the five-day workshop allowed for the breakdown of stereotypes and the dispelling of myths. Issues regarding ethnic and gender differences were highlighted throughout the week allowing for opportunities to model effective behaviors that create safe environments for all youth regardless of gender or ethnicity.

- There exists a foundation for starting 4-H clubs in the Kurdistan region. Currently, the majority of 4-H activities are located in the central and southern regions of Iraq. This workshop provided the necessary information, tools, and contacts for Kurdistan regional participants to learn more about initiating 4-H clubs in their provinces.

\section{Conclusion}

At best, curriculum development is a lengthy, cognitive process grounded in theory that requires extensive knowledge of the curriculum development writing process combined with knowledge of the technical subject matter built upon essential standards and measured by indicators. Successful curriculum writing efforts are then pilot tested at the age-appropriate developmental level before scaling up and made available to a broader audience. The five days that the facilitation team had with the workshop participants was simply not long enough to provide for adequate time in training to produce a youth development curriculum product for widespread distribution.

However, the efforts involved in this project create a solid foundation upon which to build future youth oriented curriculum development efforts in Iraq. The conference was a first for several of the participants and relationships developed as a result of the week long interactions. It is recommended that future efforts focus on longer term arrangements with Iraqi youth workers that allow for multiple points of contact in-country, to provide oversight for the curriculum writing, testing, and revision and distribution efforts necessary for widespread adoption of the youth development curriculum developed. In addition, providing opportunities for Iraqi youth workers to work along with youth partners in other countries would strengthen their programs. This approach to strengthening $4-\mathrm{H}$ youth development programs may be applicable to other countries.

\section{References}

Enfield, R.P, Schmitt-McQuitty, \& Smith, M.H. (2007). The development and evaluation of experiential learning workshops for 4-H volunteers. Journal of Extension [On-line], 45(1) Article 1FEA2. Available at: http://www.joe.org/joe/2007february/a2.php

History of 4-H. Available at: http://www.4-h.org/about/4-h-history/. 4-H.org. 
Iraqi Civil Society Solidarity Initiative. (2011, October). Final declaration of the third Iraqi Civil Society Solidarity Initiative (ICSSI) Conference: Another Iraq is possible with peace and human rights. Available at: http://www.iraqicivilsociety.org/wp-content/uploads/2011/11/FinalDeclaration-Erbil-Conference-En.pdf

Kryiakou, N. (2005). Life in 'liberated' Iraq a disaster, UN report says. FinalCall.com News. Retrieved from: http://www.finalcall.com/artman/publish/article 2023.shtml

Lerner, R.M., Almerigi, J.B., Theokas, C. \& Lerner, J.V. (2005). Positive youth development a view of the issues. The Journal of Early Adolsecence, 25(1). Available at: http://jea.sagepub.com/content/25/1/10

McPeake, J. (2011, July 7). Iraq 4-H program growing. Southeast AGNet. Retrieved from: http://southeastagnet.com/?s=4-h+program+growing

National 4-H Council. (2009). Essential Elements of 4-H Youth Development Programs. Available at: http://www.4-h.org/resource-library/professional-development-learning/4-h-youthdevelopment/youth-development/essential-elements/

Scott, K. (2011, July 5). USDA employee founds 4-H in Iraq, brings hope to Iraqi youth. USDA Blog. Retrieved from: http://blogs.usda.gov/2011/07/05/usda-employee-founds-4-h-in-iraqbrings-hope-to-iraqi-youth/

Vanwinkle, R., Busler, S., Bowman, S.R., \& Manoogian, M. (2002). Adult volunteer development: Addressing the effectiveness of training new 4-H leaders. The Journal of Extension, 40(6), 6FEA4 Available at: http://www.joe.org/joe/2002december/a4.php

Wells, M.S. \& Arthur-Banning, S.G. (2009). Mapping out your success: Using mind maps to evaluate youth development programs. Journal of Youth Development, Bridging research and practice, $4(2)$. Retrieved from http://data.memberclicks.com/site/nae4a/JYD 090402final.pdf

(C) Copyright of Journal of Youth Development $\sim$ Bridging Research and Practice. Content may not be copied or emailed to multiple sites or posted to a listserv without copyright holder's express written permission. Contact Editor at: patricia.dawson@oregonstate.edu for details. However, users may print, download or email articles for individual use.

ISSN 2325-4009 (Print); ISSN 2325-4017 (Online) 